\title{
Teachers' Opinions towards Inclusive Education Interventions in Turkey
}

\author{
Osman Aktan
}

Dr., MEB, Turkey, karakteregitimi@gmail.com

\begin{abstract}
The purpose of this research is to determine the opinions of teachers for inclusive education interventions in Turkey. In the research, a holistic single case study pattern, which is one of the qualitative research methods, was employed. The study group of the research consists of twentyeight teachers selected according to the maximum variation sampling method in the 2018-2019 academic year. In the research, teacher opinions were collected through a semi-structured interview form, whose validity and reliability were tested with a pilot study, created by the researcher and content analysis method was utilized to analyze the data. According to the research findings, most of the teachers have negative views on inclusive education due to the current conditions. In inclusive education, it was been discovered that there are problems such as professional deficiencies of teachers, insufficient support services, insufficient cooperation among partners, crowded classes, unqualified schools in terms of physical infrastructure, lack of expert support and leaving all responsibility to teachers during interventions. It was determined that the desired efficiency could not be obtained from inclusive education interventions due to the existing problems. Therefore, it was stated in this research that in order to ensure the quality of inclusive education interventions, it is necessary to include awareness-raising studies, strengthen physical infrastructure and human resources, and enable cooperation mechanisms. Based on the findings of the research, improving professional competencies of teachers, strengthening human resources in special education services, increasing the number of staff, enriching the content of special education courses in undergraduate programs and preparing the infrastructure of schools for inclusive education interventions was proposed.
\end{abstract}

Keywords: special education, inclusive education, inclusive education interventions, teacher

\section{INTRODUCTION}

One of the main concerns in contemporary education systems is the consideration of individual differences. In line with this understanding, the education concept expressed with the special education term was developed (Aktan, 2018). While special education, on the one hand, is an educational intervention that aims to prevent the disability of individuals with special needs from transforming into obstacles by enabling them to respond to their own needs, to fit into the society, to become independent and productive individuals, it, on the other hand, also aims to help gifted individuals to develop their features at the highest level (Ataman, 2011). Special education is the provision of comprehensive, research-based assessment, teaching and support services in specially prepared programs to students with disabilities or gifted students in cognitive, behavioral, socio-affective, physical and sensory forms (Bryant, Smith \& Bryant, 2008; Salend, 2011).

Determining the educational needs of students with special needs, providing them with educational settings and services in accordance with their needs contributes significantly to their participation as independent and productive individuals in the society (Şahbaz \& Kalay, 2010). It is imperative that individuals who need special education benefit from appropriate educational opportunities in order to complete their development at the highest level in line with their needs (Mastropieri \& Scruggs, 2010).

Citation: Aktan, O. (2021). Teachers' Opinions towards Inclusive Education Interventions in Turkey. Anatolian Journal of Education, 6(1), 29-50. https://doi.org/10.29333/aje.2021.613a 
According to the Ministry of National Education (MoNE) Special Education Services Regulation (2018), individuals with special needs are grouped as individuals with intellectual disabilities, individuals with hearing impairments, individuals with visual impairments, individuals with physical disabilities, individuals with language and speech difficulties, individuals with special learning disabilities, gifted individuals, individuals with autism spectrum disorder and individuals with attention deficit and hyperactivity disorder.

Although the opinion that specialization and special planning is important in the education of students who need special education still persists today, the opinion that these children should receive education in a regular education setting with their typically developing peers has become more widely accepted. This intervention which is called inclusion aims to provide individuals who are affected by disability for any reason and in need of special education with education with their typically developing peers by offering supportive education (De Boer, Pijl, \& Minnaert, 2010). Inclusive education interventions which restricts students with special needs from their peers and environment least is based on the policy that these students should be educated in regular classes. This is the model most widely adopted and being developed in the world as well as in Turkey (Armstrong, 2008). While this intervention was called inclusion in the first years, currently the term "integration" has also been come into use (Avramidis \& Norwich, 2002; MoNE, 2013).

With inclusive education interventions, students with special needs are provided with a learning environment in the classroom that allows each student to progress at their own pace of development (Salend, 2011). This means that the physical conditions and syllabus of the school are arranged so that students with moderate and severe disabilities can also continue formal education (MoNE, 2013). Inclusive education interventions requires the arrangement and the necessary improvements to be made to meet the needs of all students, including individuals with special needs in the curriculum and in the physical structure of the school, where these students can be trained in the same settings as their peers in general education schools. These interventions are based on the idea of in-group individualization in order to maintain the education efficiently. The philosophy of inclusive education practices is the adaptation of the school for the child rather than the adaptation of the child to the school (Reform in Education Initiative [REI], 2011).

The purpose of inclusive education interventions is to enable individuals with special needs to interact with other peers of all groups and levels and to achieve their educational objectives at the highest level (MoNE, 2017). In effective inclusive interventions, the education system aims the development of all learners. To this end, while placing students in general education classroom settings, arrangements are made to ensure social acceptance of inclusive students by considering their features (Salend, 2011). In addition, inclusive education interventions enable students without disabilities not only to recognize individuals with special educational needs but also to understand and comprehend individual differences more easily (De Boer, Pijl \& Minnaert, 2010). The morale of students with special needs is also lifted when they are in the same environment as typically developing children and they can learn many behaviors from their peers (Cagran \& Schmidt, 2011).

Processes for inclusive education interventions in Turkey was guaranteed legally in 1997 with the No. 573 enacted Decree Law on Special Education. Later on, the law numbered as 5387 on individuals with disabilities in 2005, the Special Education Services Regulations which was updated in 2006, 2012, 2018, and the regulations regarding education interventions through inclusion / integration in 2008 and 2017 were enacted, respectively (Ataman, 2017, MoNE, 2017 MoNE, 2018). In line with these laws and regulations, inclusive education interventions are practiced in schools. The total number of students who need special education studying in formal education institutions affiliated to the Ministry of National Education is 398,815. This rate constitutes approximately $2.2 \%$ of the total number of students studying in formal education institutions. $14 \%$ of students with special needs 
continue their education in special education classes, $12 \%$ in special education schools and $74 \%$ continue their education as an inclusion student (MoNE, 2019). It can be said that most students with special needs in Turkey benefit from inclusive education interventions.

When the related literature is examined, it is determined that there are many researches on inclusive education interventions, and it is also seen that different problems were experienced in inclusive education interventions based on the results of these studies. To illustrate, in some of the research on inclusive education interventions, it was found that teachers have negative attitudes towards inclusive education interventions (Aktan, 2017; Combs, Elliott \& Whipple, 2010; Coşkun, Tosun \& Macaroğlu, 2009; De Boer, Pijl \& Minnaert, 2011; Kayhan, Şengül \& Akmeşe, 2012; Obiakor, Harris, Mutua, Rotatori \& Algozzine, 2012). Besides, in some other studies, it was detected that teachers see themselves insufficient in terms of inclusive education interventions both in terms of knowledge and experience (Babaoğlan \& Y1lmaz, 2010, Block \& Obrusnikova, 2007; Carroll, Forlin \& Jobling, 2003; Cassady, 2011; Sadioğlu, Bilgin, Batu \& Oksal, 2013; Shady, Luther \& Richman, 2013). There are also other studies that determine the insufficiency of the education provided to undergraduate students regarding special education as in Gökdere (2012), and Gözün and Yıkmış (2004). In their studies, while Andrews and Frankel (2010), Fuchs (2010), and McCray and McHatton (2011) concluded that inclusive education places additional responsibilities on the teacher, Gökdere (2012) underlined the conclusions he drew regarding the insufficiency of support services in inclusive education. Finally, there are some studies whose results suggest that there is a lack of cooperation in interventions (Taylor, Smiley \& Richards, 2009; Lee \& Low, 2013; Adams, Harris \& Jones, 2016). When the results of these studies are evaluated, it can be said that there are persisting problems about different issues related to inclusive education.

\section{Significance of the Research}

Most of the students with special needs studying in formal education institutions affiliated to the Ministry of National Education continue their education in general education classes as inclusive students (MoNE, 2019). Inclusive education interventions are based on the understanding that individuals with special needs who will spend most of their lives in the society they live should continue their education in the same educational environments as their peers to ensure social cohesion and acknowledgment, rather than special educational settings separate from their peers. In the education of individuals with special needs, the opinions of teachers who have experience and knowledge in inclusive education interventions are important to improve the quality of inclusive education interventions in Turkey, to detect problems in current interventions and to develop strategies regarding the solution of these problems.

Other factors increasing the significance of this research are that most of the research on the inclusive education in Turkey are quantitative and the number of qualitative research studying teachers' opinions with a good number of participants is insufficient. In addition, some arrangements have been made with recent regulations and legislative amendments regarding inclusive education. Therefore, it can be said that the results obtained in the research are also important in terms of contributing to the review of policies regarding inclusive education, as they are the reflections of legal regulations on inclusive education in practice.

\section{Aim of the Research}

The aim of this research is to determine the opinions of teachers regarding inclusive education interventions in Turkey. To this end, the answers for the following sub-goals were sought.

1. What are the opinions of the teachers regarding the current inclusive education interventions?

2. What are the opinions of teachers about risk and threats in inclusive education interventions?

Anatolian Journal of Education, April $2021 \bullet$ Vol.6, No.1 
3. What are the opinions of the teachers about ensuring the desired quality in inclusive education interventions?

\section{METHOD}

\section{Design of the Research}

In this qualitative research, where the opinions of teachers regarding inclusive education interventions in Turkey were determined, a holistic single case research design was used. In the case study, there is an in-depth analysis of one or more events, facts, environments, individuals, groups, programs, social groups, society or other restricted system. The case refers to a holistic system (Yin, 2011). The holistic single case design, on the other hand, is the revelation of results by in-depth examination of a single case under investigation (Yıldırım \& Şimşek, 2013). In this study, the determination of teacher opinions on inclusive education interventions was considered as a single case. Since the research involves a single analysis case, it was designed as a holistic single case study.

\section{Study Group}

Maximum variation sampling, which is one of the purposeful sampling methods, was utilized to form the study group of the research. The purpose of creating a sample based on maximum variation is to try to find out whether there are any common or shared cases among the varying cases and to reveal different dimensions of the problem according to this variety (Patton, 2014). The study group of the research was selected among the teachers participating in an in-service training program at the national level. In order to ensure the diversity in the study group, different features such as geographical region and province, gender, professional seniority, branch, education status, having at least five years of professional experience in inclusive education interventions and having an inclusion student in the class were taken into consideration. Thus, the study group of the research consisted of twenty-eight teachers selected according to these features.

\section{Data Collection Tool}

In this study, semi-structured interview form was used as data collection tool. In semi-structured interviews, pre-determined questions can be asked consistent with the purpose of the research, or additional questions can be asked to get more in-depth information (Yıldırım \& Şimşek, 2013). The scope and face validity of an assessment tool can be evaluated with expert opinions (Büyüköztürk, 2017). In the research, a teacher interview form was prepared in order to determine the opinions of the participants regarding inclusive education interventions. The following steps were followed in the preparation of the interview form, testing the validity and reliability:

- A draft interview form with four questions and four probe questions related to these questions was prepared.

- The opinions of four experts one of whom was a language expert were received on the draft.

- The form was finalized by making necessary corrections in line with the opinions of the experts.

- In order to test the validity and reliability of the interview form, a pilot application of the interview form was conducted with four teachers having different seniority status, educational background, branch and gender.

- The clarity of the questions in the interview form was checked, and their validity and reliability were tested. It was observed that the interview form served the purpose. 
- After obtaining expert opinions and applying pilot interviews, the questions in the interview were finalized and a final interview form with three questions was prepared.

- The interview form has three questions which are "What are your views on current inclusive education interventions? What are your opinions on risks and threats in terms of inclusive education interventions? What are your opinions on ensuring the desired quality in inclusive education interventions?" and probe questions about these questions.

\section{Data Analysis}

In the research, the teacher interview forms were analyzed using content analysis method. Content analysis can be defined as a systematic, repeatable technique in which some words of a text are summarized with smaller content categories with coding based on certain rules (Büyüköztürk, 2017). The main purpose in content analysis is to reach concepts and relationships that can explain the collected data. For this purpose, the collected data must be conceptualized first. Then they need to be arranged in a logical manner according to the findings that have obtained and the themes that explain the data must be determined accordingly (Yıldırım \& Şimşek, 2013). The interview forms were analyzed through content analysis and themes and sub-themes were created. The creation of the themes was based on the sub-aims of the research and the codes that were obtained from the interview form. The teachers interviewed were coded as T1, T2, T3.

\section{Validity and Reliability Studies}

Various strategies are employed in order to ensure validity and reliability in qualitative research (Creswell, 2014). This research was conducted in accordance with the qualitative research tradition to increase the validity of the results of the study. In order to ensure internal validity in the research, each teacher was given a code in the analyzes, the data were analyzed, and themes and sub-themes were reached. In addition, the steps of the study such as the method of the study, the creation of the study group, the preparation and implementation of the data collection tool, the analysis of the data, the validity and reliability were explained in details, and the researcher was effective at every stage of the research.

In addition to aforementioned implementations above, some other things were done in order to collect in-depth data. The first one is to ensure variation in the features of the participants. Then the confirmation of the participants was taken for two reasons: First, to prevent errors that may arise from the processes and subjective assumptions regarding the examination of the co-expert in the development of the data collection tools and second, to determine the opinions correctly. Purposeful sampling method was used to ensure the external validity of the research, and the data set was studied in detail. While coding, organizing themes and sub-themes, the raw version of teacher opinions was taken as basis. For this purpose, the data were described in detail using direct quotations from teacher views. In order to ensure the reliability of the data obtained, "Consensus / (Consensus + Disagreement) x 100" formula of Miles and Huberman (2015) was used. The reliability rate between the expert opinions regarding the coding was determined to be $92 \%$.

\section{FINDINGS}

Findings obtained as a result of the interviews were presented as sub-problems.

\section{Findings and Interpretations on the First Sub-Problem}

The first sub-problem was expressed as "What are the opinions of the teachers regarding the current inclusive education interventions?" The teachers' opinions on current inclusive education interventions 
were gathered under one theme and two sub-themes. The teachers' views on the inclusive education interventions theme were presented in Table.

Table 1

The opinions of the teachers on current inclusive education interventions

\begin{tabular}{|c|c|c|c|}
\hline Theme & Sub-themes & Opinions & Frequency $(\mathrm{F})$ \\
\hline \multirow{7}{*}{ 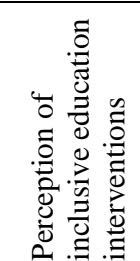 } & Feasibility & Negative perception & 21 \\
\hline & & Positive perception & 7 \\
\hline & \multirow{5}{*}{$\begin{array}{l}\text { Current } \\
\text { Status }\end{array}$} & Teachers' having negative attitude & 16 \\
\hline & & Not attaining the desired success & 14 \\
\hline & & School administrators' having negative attitude & 12 \\
\hline & & Lack of social awareness & 7 \\
\hline & & Families' having negative attitude & 3 \\
\hline
\end{tabular}

In Table 1 above, it can be seen that the opinions of the teachers regarding the inclusive education were gathered under the feasibility and current status sub-themes. Negative perception in the feasibility sub-theme ( $f=21)$ and teachers' negative attitudes $(f=16)$ in the current situation subtheme are the prominent opinions when considering the opinions of the teachers. Below are the quotes from the participating teachers on the perception of inclusive education interventions.

"I do not think that inclusive education is properly practiced under the current conditions, most interventions remain on paper. Not feasible in the classroom. Are you going to cover all the topics you need to do in a thirty-five or forty-student class, or spend the time with inclusive students? It is very difficult in practice (T24)".

"I think it has no feasibility in practice. It is necessary to deal with these students individually. For example, the student is a middle school student but has behavioral problems, or problems in reading and writing. Will you handle the class or the student? (T1)'”.

"Due to the insufficient social acceptance towards the individuals with special needs in the society and negative attitude, we have problems in inclusion. The society should also be ready for this (T12)".

\section{Findings and Interpretations on the Second Sub-Problem}

The second sub-problem was expressed as "What are the opinions of teachers about risk and threats in inclusive education interventions?". The teachers' opinions on risks and threats in current inclusive education interventions were gathered under one theme and two sub-themes. In Table 2, the teachers' views on the risk and threats in inclusive education interventions theme were given. 
Table 2

Teachers' opinions on risks and threats in current inclusive education interventions

\begin{tabular}{|c|c|c|c|}
\hline Theme & Sub-themes & Opinions & Frequency $(\mathrm{F})$ \\
\hline \multirow{16}{*}{ 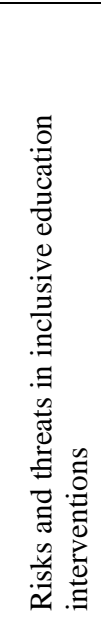 } & \multirow{4}{*}{$\begin{array}{l}\text { Prior to } \\
\text { intervention }\end{array}$} & Negative attitudes & 19 \\
\hline & & The society that is not ready & 13 \\
\hline & & Insufficient social acceptance & 11 \\
\hline & & Lack of empathy & 6 \\
\hline & \multirow{12}{*}{$\begin{array}{l}\text { intervention } \\
\text { Phase }\end{array}$} & $\begin{array}{l}\text { Teachers' professional insufficiency regarding } \\
\text { inclusive education }\end{array}$ & 22 \\
\hline & & Insufficiency of support services & 19 \\
\hline & & Insufficiency of cooperation between parties & 16 \\
\hline & & Crowded classes & 16 \\
\hline & & Insufficient physical infrastructure of schools & 13 \\
\hline & & Not having expert support & 11 \\
\hline & & Leaving all responsibilities to teachers & 9 \\
\hline & & Concerns of parents of typically developing students & 5 \\
\hline & & Lack of auxiliary staff & 4 \\
\hline & & Frequent change of regulations & 2 \\
\hline & & Failure in achieving conceptual unity & 2 \\
\hline & & Negative perception of typically developing students & 1 \\
\hline
\end{tabular}

In Table 2, the teachers' opinions on risks and threats in current inclusive education interventions were gathered under prior to intervention and intervention phase sub-themes. Based on the teachers' opinions, negative attitudes, in the prior to intervention sub-theme, $(\mathrm{f}=19)$ and teachers' professional insufficiency regarding inclusive education, in the intervention phase sub-theme, $(\mathrm{f}=22)$ are the prominent opinions. Below are the quotes from the participating teachers on the risks and threats in current inclusive education interventions theme.

"The current infrastructure of schools is insufficient for all disability groups. Support services are insufficient, there are no auxiliary staff. There is no expert to whom we can get support. In the current intervention, we are left to our own destiny, we cannot be sufficient for students. For example, some students with hearing and visual impairment, and autism spectrum disorder require more expertise and professional knowledge. These are serious problems for intervention (T14) ".

“... The perception of administrators and teachers except for special education teachers towards the current inclusive interventions which enable individuals with special needs to be with their peers at every stage of education is negative. Parents have complaints claiming, for example, that they set a bad example to their children etc. I think these negative thoughts are a serious obstacle to the success of the current interventions (T23)".

"Schools are not sufficient in terms of physical infrastructure, activity areas, sports facilities and other support services (T10)”.

"Some families have concerns regarding the intervention. For example, they do not want inclusive students and their children to communicate and keep their distance. This attitude affects these children. These are serious problems (T5)".

"Inclusive education seems to be left to the teacher, which seems to be the responsibility of the guidance service. Not all parties are taking enough responsibility, and it is necessary to clarify the name of the intervention. I mean are we expected to help them socialize or educate these students? A clear definition should be used (T8)". 


\section{Findings and Interpretations on the Third Sub-Problem}

The third sub-problem was expressed as "What are the opinions of the teachers about ensuring the desired quality in inclusive education interventions? The opinions of the teachers on promoting the desired quality in inclusive education interventions were collected under a single theme and four subthemes. The opinions of the teachers about promoting the desired quality in inclusive education interventions were presented in Table 3.

Table 3

The opinions of the teachers on promoting the desired quality in inclusive education interventions

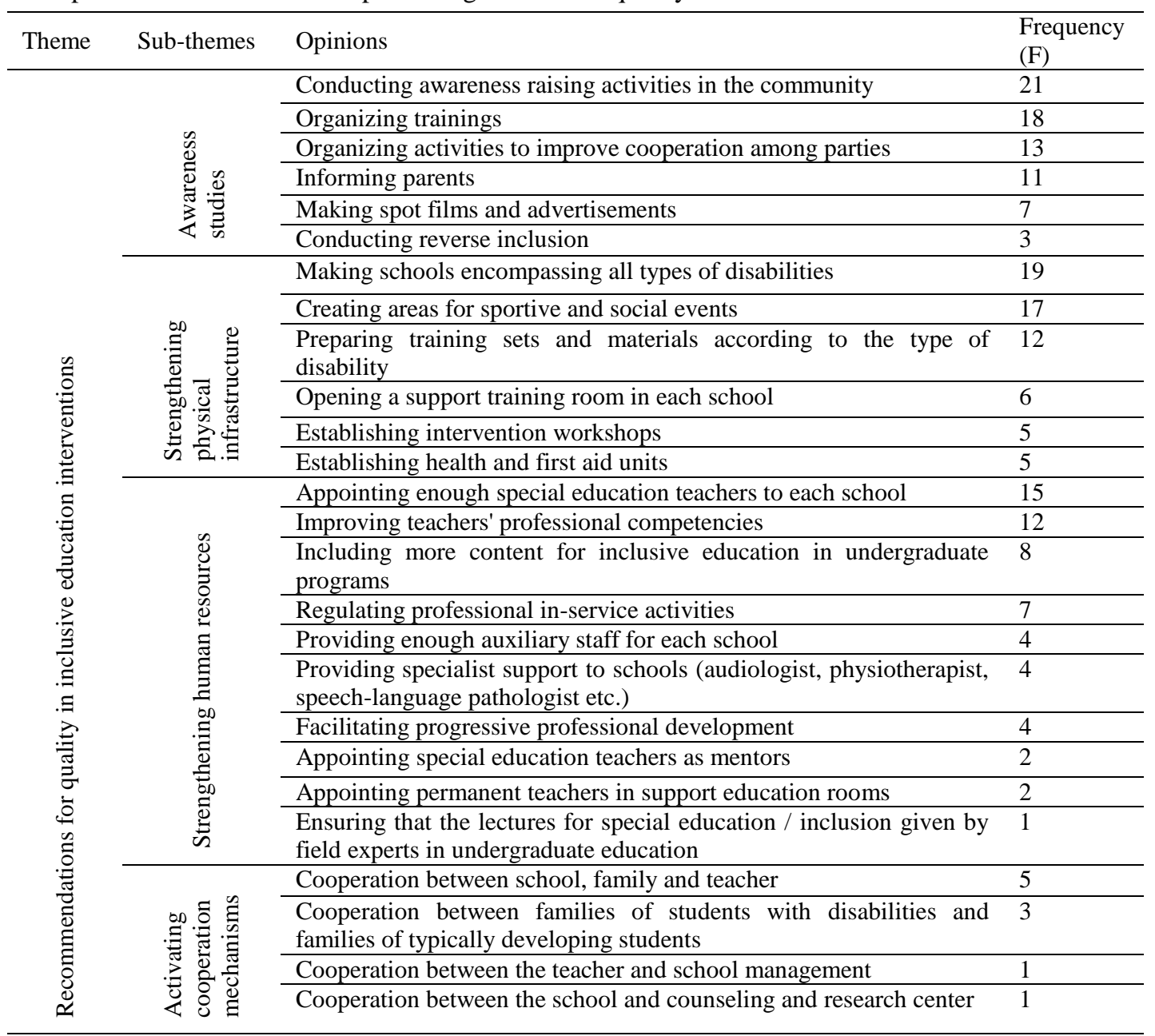

As can be seen in Table 3, the opinions of teachers on the ensuring the desired quality in inclusive education interventions theme were gathered under the awareness studies, strengthening physical infrastructure, strengthening human resources and activating cooperation mechanism's sub-themes. In line with the opinions of the teachers, conducting awareness raising activities in the community ( $\mathrm{f}=$ 21 ) in the awareness studies sub-theme; In the strengthening physical infrastructure sub-theme, making schools encompassing all types of disabilities $(f=19)$, and in the strengthening human resources sub- 
theme, appointing enough special education teachers to each school ( $\mathrm{f}=15)$; cooperation between school, family and teacher in the activating cooperation mechanisms ( $f=5$ ) sub-theme are the prominent opinions. Below are direct quotations from the teachers' views regarding the ensuring the desired quality in inclusive education interventions theme.

“... Short films and public spots for the society can be prepared (T20)”.

"The awareness that living together with people with disabilities not only in school but everywhere should be fostered. Accordingly, awareness raising activities should be conducted for typically developing students starting from pre-school. Trainings for families, teachers and parents can be organized. These trainings should be given by experts who are trained in the relevant field. In addition, family, teacher and school cooperation should be promoted (T7) ".

"The understaffing problem should be eliminated, and sufficient number of specialists such as special education teachers, speech-language pathologist, physiotherapists and auxiliary personnel should be given to each school. There should be a nurse, for example, we have students who have chronic health problems such as epilepsy. Besides, since teachers have a busy schedule, it is difficult to find a teacher to be assigned for support education (T6)".

"Lectures for inclusive and special education in undergraduate education should be more and they should definitely be given by field experts. Pre-service teachers should meet and work with inclusive students on the field before graduation. Teachers should be qualified on inclusive education when they start working on the field (T27)".

\section{DISCUSSION}

Below, the results concerning teacher opinions were given as sub-problems and compared with the results of other studies in the literature and then they were discussed.

\section{Discussion Regarding the First Sub-problem}

According to the results of the research, it was determined that teachers have negative attitudes and thoughts about the intervention of inclusive education. It was also discovered that teachers, administrators and parents have negative attitudes towards existing inclusive education intervention, there is no social awareness at the desired level, which affects inclusive education negatively. Similar to our research findings, in many studies conducted on inclusive education interventions, it was found that teachers have negative views about inclusive education interventions (Avramidis \& Norwich, 2002; Ceylan \& Aral, 2016; Donohue \& Bornman, 2014; Haug, 2017; Glazzard, 2011; Mateusi, Khoaeane \& Naong, 2014; O'Gorman \& Drudy, 2011; Sadioğlu, Batu \& Bilgin, 2013; Saraç \& Çolak, 2012), teachers have problems in inclusive education due to the problems they experience (Akalın, 2015; Yatgın, Sevgi \& Uysal, 2015). In addition, there are findings in the literature supporting the results of our research. For example, in their studies Demirezen \& Akhan (2016), and Güven \& Balat (2006) found that the desired efficiency could not be attained from existing inclusive education interventions. Likewise, it was also detected that teachers were not willing to work with students with special needs (Avramidis \& Norwich, 2002; Scruggs \& Mastropieri, 1996), and they did not want inclusive students in their classes (Saraç \& Çolak, 2012; Yatkın, Sevgi \& Uysal, 2015).

In some studies, contrary to our research findings, results suggesting that teachers support inclusive education were obtained. To illustrate, it was determined that the majority of the participating teachers had positive thoughts about inclusive education (Scruggs \& Mastropieri, 1996) and inclusive education is a useful intervention for students (Yaylac1 \& Aksoy, 2016). Problems arising due to the failure in fulfilling the duties and responsibilities properly regarding inclusive education interventions can be argued to be the reason in the emergence of this difference. According to the findings of the 
research, it can be said that the majority of the teachers who participated in the research had negative thoughts about inclusive education interventions and the problems experienced in inclusive education were an important factor in the formation of these thoughts that decrease the quality of inclusive education.

\section{Discussion Regarding the Second Sub-problem}

According to the results of the research, it was determined that negative attitudes towards inclusive education are one of the most important risks and threats in terms of inclusive education interventions. Considering the related literature, it can be said that the results of the research in which teacher attitudes towards inclusive education were discussed are similar. In inclusive education interventions, teachers' negative attitude towards the intervention is among the main problems (Combs, Elliott \& Whipple, 2010; Coşkun, Tosun \& Macaroğlu, 2009; DeBoer, Pijl \& Minnaert, 2011; Kayhan, Şengül \& Akmeşe, 2012; Obiakor Harris, Mutua, Rotatori \& Algozzine, 2012; Şahbaz \& Kalay, 2010). As for the reasons why teachers develop negative attitudes towards inclusion, the prominent ones are teachers' feeling inadequate in terms of both knowledge and experience (Babaoğlan \& Y1lmaz, 2010, Block \& Obrusnikova, 2007; Cassady, 2011; Sadioğlu, Bilgin, Batu \& Oksal, 2013; Shady, Luther \& Richman, 2013), inadequate lectures on special education during undergraduate education (Gökdere, 2012; Gözün \& Y1kmıș, 2004) and additional responsibilities encumbered on the teacher due to inclusive education (Andrews \& Frankel, 2010; Coşkun, Tosun \& Macaroğlu, 2009; Fuchs, 2010; McCray \& McHatton, 2011). In order to ensure that teachers have positive attitudes and thoughts regarding inclusive education interventions, it is necessary to improve the pre-service and post-service professional competencies of teachers and to provide specialist and auxiliary support services for teachers.

According to the results of the research, the society that is not ready, insufficient social acceptance and lack of empathy are other important risks and threats in terms of inclusive education interventions. In the research conducted on inclusive education such similar results that there is a lack of social acceptance for inclusive education (Forlin, Loreman, Sharma \& Earle, 2009; Sharma, Forlin \& Loreman, 2008; Sharma, Loreman \& Forlin, 2011) and the social acceptance for students with special needs is inadequate (Ceylan \& Aral, 2016; Saraç \& Çolak, 2012; Yatkın, Sevgi \& Uysal, 2015) were obtained. Considering the results of the research, it can be said that negative attitudes towards the intervention are caused by problems such as insufficient social awareness, lack of both social acceptance and empathy.

As far as the results of our research are concerned, among the risks and threats to inclusive education; teachers' professional insufficiency, insufficient support services, insufficient cooperation between the parties, crowded classes, inadequate physical infrastructure of schools, and inability to provide expert support have an important place. Besides, leaving all responsibilities to teachers, concerns of parents of typically developing students, lack of auxiliary staff, changing the regulations frequently, failure in achieving conceptual unity and the negative perception of typically developing students are other important risks and threats to inclusive education. Similar results supporting our research findings were revealed in the studies on inclusive education. In these studies, it was found that teachers do not consider themselves professionally adequate for inclusive education (Babaoğlan \& Y1lmaz, 2010, Block \& Obrusnikova, 2007; Cassady, 2011; Shady, Luther \& Richman, 2013), and the courses taken for special education during undergraduate education are inadequate (Gökdere, 2012; Gözün \& Y1kmış, 2004). In addition to this, it was also detected that support services for inclusive education are inadequate (Çankaya \& Korkmaz, 2012; Demir \& Açar, 2011; Fuchs, 2010; Gökdere, 2012; Sadioğlu, Batu \& Bilgin, 2012) and the required collaborations cannot be achieved (Abongdia, Foncha \& Dakada, 2015; Adams, Harris \& Jones, 2016; Demir \& Açar, 2011; Fuchs, 2010; Slobodzian, 2009; Taylor, Smiley \& Richards, 2009; Lee \& Low, 2013). Moreover, crowded classes (Abongdia, Foncha 
\& Dakada, 2015; Akalın, 2015; Çankaya \& Korkmaz, 2012; Demir \& Açar, 2011; Demirezen \& Akhan, 2016; Hui, 2015) and insufficient physical infrastructure of schools (Bruwer, Hartell \& Steyn, 2014; Haug, 2017) were determined to affect inclusive education negatively. It can be said that the results of our research are similar to those of the studies in the literature, and not only the risks and threats to inclusive education but the problems that negatively affect the quality of inclusive education persist.

According to the results of the research, it was determined that the conceptual cohesion related to inclusive education was not provided and both inclusion and integration concepts are used in practice. Similarly, in studies conducted in special education, the integration concept is used instead of the inclusion concept. Integration, regardless of individual differences, is an umbrella term that envisages all members of society to benefit from social, cultural, educational, vital activities and opportunities equally, and is considered multi-dimensional in content (Friend, Cook, Hurley-Chamberlain \& Shamberger, 2010; MoNE, 2013). Integration means that all children in the classroom receive education together in accordance with their differences and needs. Taking this into consideration, it is necessary to provide necessary physical conditions, curriculum and regulations regarding education and training methods in order to meet the needs of typically developing children and children with special needs in general education schools (REI, 2011; Rodriguez \& Garro-Gil, 2015). Similarly, it is seen that both concepts are used together in the official regulations related to special education services and related legal regulations (MoNE, 2013; MoNE, 2017; MoNE, 2018). Based on the problems experienced in inclusive education, it can be said that integration is used as a concept equivalent to inclusive education, rather than being a result that emerge from improving the interventions in the field in terms of quality.

It was determined that teachers who are not sufficient in terms of professional competence fail in inclusive education (Bubpha, Erawan \& Saihong, 2012). As a result of this, it is very difficult and problematic for the teacher to conduct inclusive education (Kuyini \& Desai, 2008). In order to improve the professional competence of teachers for inclusive education, it would be beneficial for them to participate in-service training activities systematically and voluntarily on issues such as preservice and post-service prejudices, special education knowledge, cooperation, planning of training, time management, and administrative support (David and Kuyini, 2012; Seçer, Sarı \& Çetin, 2010; Worrell, 2008). Based on the research results, it can be said that despite the problems experienced in inclusive education and many changes in legal regulations, risks and threats continue. These results require a comprehensive evaluation of inclusive education interventions in Turkey.

\section{Discussion Regarding the Third Sub-problem}

Based on the research findings, results were obtained regarding the necessity for the inclusion of not only awareness raising activities in the society, organizing trainings, but also activities to promote cooperation between parties, informing parents, preparing spot films, commercials, and reverse inclusion interventions in order to achieve the desired quality in inclusive education interventions. Children with special needs find learning opportunities in settings where they feel safe and believe that they are valued and they make the most of these opportunities (Deiner, 2010). Achieving individual and social acceptance towards disabled people, creating positive attitudes towards them, and creating social awareness about individuals with special needs can also contribute.

In the light of the research findings, schools' physically addressing all disability groups, creating sports and social activity areas, preparing training sets and materials according to the disability types was found to be necessary. Besides, opening a support training room, establishing health and first aid units and intervention workshops where children with and without special needs to collaborate in every school was stated to be important to make schools ready for inclusive education interventions. The findings of studies on inclusive education underlining the importance of improving schools in 
terms of physical infrastructure also support the findings of our research. Learning environments in inclusive education are very effective in increasing student participation and learning opportunities (Sucuoğlu \& Akalın, 2010). The physical setting of inclusive classes should be sufficient in terms of equipment and number of students. The fact that the class size is not too crowded can be effective in the positive attitude of the teacher towards inclusion (Batu \& Kırcaali-Iftar, 2011). The class in which the inclusive interventions is conducted should be designed to attract students' attention in terms of physical features and equipment and encourage them to participate in learning settings. The seating arrangement in classrooms should be planned in such a way that children can move easily and interact with each other (Batu \& Kırcaali-İftar, 2011; Batu \& Uysal, 2010). According to the opinions of the teachers, in order to obtain the necessary efficiency in inclusive education interventions, physical infrastructure of schools and classes should be planned to meet the needs of students.

Based on the research findings, it can be said that in some schools where inclusive education is practiced, the lack of a support training room is a serious deficiency in terms of the support provided to students with special needs, and the expansion of these rooms may positively affect the quality of the inclusive education. In some research conducted on support training rooms, it was concluded that the students who received training in the support rooms improved their academic, social and communicative behavior skills (Gürgür, Kış \& Akçamete, 2012; Ünay, 2015). According to the findings of the research, it was determined that there was a problem in assigning teachers in the support training rooms due to their busy schedules. The results of some research on support training rooms also support our research findings (Güven, 2019).

According to the results of the research, it was stated that health and first aid units should be established in schools to improve the quality of inclusive education. Chronic diseases are diseases such as epilepsy, asthma, diabetes, childhood cancer, congenital heart defects, cystic fibrosis, Hepatitis B, Human Immunodeficiency Virus (HIV), Acquired Immune Deficiency Syndrome (AIDS) (Hallahan \& Kauffmann, 2003). According to Turkstat, 12.29 percent of the population in Turkey are individuals with disabilities. While chronic diseases constitute $9.70 \%$ of this figure, individuals with orthopedic, visual, hearing, speech and language and mental disabilities compromise the $2.58 \%$ (Turkey Statistics Institute [TurkStat], 2002). 2.6\% of individuals with chronic illnesses are students at school age (Turkey Disability Survey, 2002, p.5). Students with chronic illnesses also benefit from inclusive education interventions. It can be said that providing first aid support to students with chronic illness in cases of a crisis and attack is a necessary need in schools. In particular, teachers' competencies in correct intervention strategies in cases of a crisis and attack can be improved by training them about chronic diseases.

In order to strengthen inclusive education interventions in terms of human resources, some suggestions such as assigning sufficient number of special education teachers to each school, improving professional self-efficacy of teachers, providing more space for inclusive education in teacher undergraduate programs, providing sufficient number of auxiliary staff to each school were made. Some other suggestions based on the results of the research such as providing specialist support (nurse, audiologist, physiotherapist, speech-language pathologist, etc.) appropriate for the disability group, giving sustainable in-service training for teachers and benefitting from special education teachers as mentors were also made. It was also emphasized that lectures for special education and inclusive education in undergraduate education should be taught by academic staff who have field experience.

The fact that teachers and administrators have little knowledge about inclusive education and students with special needs and consider themselves insufficient in terms of professional competence prevents obtaining successful results in studies related to inclusive education (Carroll, Forlin \& Jobling, 2003; Smith, Tyler, Skow, Stark \& Baca, 2003). Improving teachers' professional competencies can 
contribute to having effective results in inclusive education interventions. However, in undergraduate teacher training education programs, there is no other course for inclusive education apart from a 2credit "Special Education and Inclusion" course (Council of Higher Education [CoHE], 2018), which can be said to be an important deficiency in inclusive education in undergraduate programs that train teachers.

In the research, it was proposed to organize in-service trainings to improve the quality of inclusive education based on the teacher opinions. In some studies on inclusive education, similar findings were obtained regarding the importance of organizing in-service trainings (Deniz \& Çoban, 2019; Gürgür \& Hasanoğlu Yazçayır, 2019; Yılmaz \& Melekoğlu, 2018). In some other research on inclusive education interventions; on the other hand, there were findings stating that the organized in-service training activities were insufficient due to lack of information for the intervention, and as a result, the desired efficiency could not be obtained from them (Begeny \& Martens, 2006; Sadioğlu, Bilgin, Batu \& Oksal, 2013; Saraç \& Çolak, 2012). Based on the findings of the research, it can be said that teachers who are involved in inclusive education need in-service training activities, but the organized trainings do not satisfy teachers in terms of content. Therefore, it would be useful to include qualified training activities for classroom interventions.

In order to make cooperation mechanisms effective in inclusive education interventions, results have been obtained for cooperation between school, family, teacher; cooperation between parents of students with and without disabilities; cooperation between teacher and school administration; cooperation between school and counseling and research center. For effective inclusive education intervention, a multi-dimensional interaction and collaboration process should be established between the parties (Taylor, Smiley \& Richards, 2009; McMillan, 2008; Lee \& Low, 2013; Metin, 2018). In research on inclusive education, the lack of cooperation among the parties has been identified as an important problem in inclusive education interventions (Çankaya \& Korkmaz, 2012; Fuchs, 2010; Hemmingsson, Gustavsson \& Townsend, 2007; Hui, 2015). For the quality of inclusive education, it can be said that our research findings for establishing cooperation between the parties are similar to the results of research in the literature.

\section{CONCLUSION}

According to the results obtained in the research, it was determined that the teachers have negative attitudes and opinions towards existing inclusive education interventions. Lack of social awareness and professional qualifications for inclusive education, insufficient support services, being alone in the intervention, lack of sufficient support from the parties and deficiencies arising from the physical infrastructure of schools can be claimed to be effective in teachers' negative attitudes and opinions. It is also an important issue for policy makers to consider that families, teachers and administrators who have to work in cooperation for inclusive education to be successful have negative attitudes. According to this result, it can be said that cooperation between the parties could not be achieved in practice and lack of cooperation in inclusive education can be argued to pose a serious threat for the success of the intervention.

In order to ensure quality in inclusive education interventions, teachers' professional competencies can be improved by increasing the content and duration regarding inclusive education in teacher education programs and by providing experience opportunities for prospective teacher candidates. Besides, considering that inclusive education is an education offered to students in different disability groups, it is necessary to provide schools with expert support in different areas, and schools should be organized so as to have the required infrastructure and equipment to meet the needs of different disability types. It can be said that social acceptance towards inclusive education can be increased with social awareness studies, which may affect inclusive education interventions positively. 
The education process for the planning, practice and evaluation of inclusive education interventions in schools should be carried out with an effective cooperation between individuals with special needs, teachers in school, school management, counselling service, and parents of students with and without special needs. The dynamic operation of this cooperation process is under the authority and responsibility of the school management. The interruption of the cooperation due to the problems experienced in the process prevents all planning and regulations for individuals with special needs from being functional.

Although necessary legal regulations have been made for the successful implementation of inclusive education interventions in Turkey, it can be said that the desired efficiency and success in inclusive education could not be achieved in Turkey due to the negative attitudes of the parties towards the intervention, the authorities who do not fulfil their responsibilities, the problems encountered in the field, the lack of support services, the lack of professional competencies of teachers, and the lack of proper supervision.

\section{RECOMMENDATIONS}

The results obtained in studies based on teacher opinions are very important for the professional work and professional development of teachers (Noyes, 2004). The results of this research obtained from the opinions of the teachers, who have a key role in inclusive education, can make significant contributions to the development of teachers' professional competencies for inclusive education interventions, developing policies for the solution of problems encountered in inclusive education interventions in Turkey, and improving the quality of inclusive education interventions.

In line with the results of our research, it is suggested that studies that will improve the attitude, social awareness and social acceptance of the parties involved in inclusive education interventions be carried out. It is also suggested to enrich the content of special education in teacher education programs, and to assign permanent teachers to support education rooms. In addition to these, it is suggested to organize practice-oriented on the job trainings for teachers to improve their professional competencies, and to conduct action research on the solution of problems in inclusive education.

\section{LIMITATIONS}

This study examining the views of teachers for inclusive education interventions in Turkey is limited to the findings obtained with the qualitative research methods. The survey results are limited to the opinions of twenty-eight teachers working in different cities in Turkey. The reliability of the research is limited by the objectivity of the teachers' answers. Therefore, the results of the research should be evaluated considering the working group of the research.

\section{REFERENCES}

Abongdia, J.A., Foncha, J.W., \& Dakada, A. (2015). Challenges Encountered by Teachers in Identifying Learners with Learning Barriers: Toward Inclusive Education. International Journal of Educational Science, 8(3), 493-501. Doi: 10.1080/09751122.2015.11890271.

Adams, D., Harris, A., \& Jones, M. S. (2016). Teacher-parent collaboration for an inclusive classroom: success for every child. The Malaysian Online Journal of Educational Science, 4 (3), 5871. Retrieved from https://files.eric.ed.gov/fulltext/EJ1106456.pdf.

Akalın, S. (2015). Kaynaştırma sınıfı öğretmenlerinin sınıf yönetimine ilişkin görüşleri ve gereksinimleri [Opinions and needs of mainstream classroom teachers about classroom management]. Ankara Üniversitesi Ĕgitim Bilimleri Fakültesi Özel Ĕgitim Dergisi [Ankara University Faculty of 
Educational Sciences Journal of Special Education], 16(3), 215-234. Doi: 10.1501/Ozlegt_0000000230.

Aktan, O. (2017). Classroom teachers' opinions regarding educational practices through integration in special education, in Current debates in education, Ed. Akfirat, N., Staub, D.F. \& Yavaş, G., Vol.5, 171-188. London: IJOPEC Publication.

Aktan, O. (2018). Kaynaştırma eğitiminde takım destekli bireyselleştirme tekniğinin öğrencilerin ders başarısı derse karşı tutum ve sosyal kabul düzeylerine etkisi.[The Effect of Team-Assisted Individualization Technique on the Academic Successes of the Students, Attitude to Lessons and Social Acceptance in Inclusive Education]. Yayınlanmamış Doktora Tezi. Gazi Üniversitesi. Eğitim Bilimleri Enstitüsü, Ankara. Retrieved from https://tez.yok.gov.tr/UlusalTezMerkezi/

Andrews, A., \& Frankel, E. (2010). Inclusive Education in Guyana: A Call For Change. International Journal Of Special Education, 25(1), 126-144. Retrieved from https://files.eric.ed.gov/fulltext/ej890573.pdf.

Armstrong, F. (2008). Inclusive education. In G. Richards \& F. Armstrong (Eds.), Key issues for teaching assistants. Working in diverse and inclusive classrooms. London and New York: Routledge.

Ataman, A. (2011). Özel eğitime giriş. [Introduction to special education]. A. Ataman (Ed.). Özel gereksinimli çocuklar ve özel eğitime giriş içinde [In Children with special needs and introduction to special education]. (19-74). Ankara: Gündüz Eğitim.

Ataman, A. (2017). Özel eğitime muhtaç olmanın nedenleri, anlamı ve amaçları. [Reasons, meaning and objectives of needing special education]. Ataman, A., (Ed.). Temel eğitim ögretmenleri için kaynaştırma uygulamaları ve özel eğitim içinde [In İnclusive practices and special education for elementary education teachers] (s.3-25). Ankara: Vize.

Avramidis, E., \& Norwich, B. (2002). Teachers' attitudes towards integration / inclusion: A review of the literature. European Journal of Special Needs Education, 17(2), 129-147. Doi: 10.1080/08856250210129056.

Babaoğlan, E., \& Yılmaz, Ş. (2010). Sınıf öğretmenlerinin kaynaştırma eğitimindeki yeterlilikleri. [Competency of Classroom Teachers in The Inclusive Education]. Kastamonu Eğitim Dergisi [Kastamonu Education Journal], 18(12), 343-354. Retrieved from http://www.kefdergi.com/pdf/18_2/18_2_1.pdf.

Batu, S., \& Uysal, A. (2010). Günümüz sınıflarına engelli çocukların katılımını destekleme [Supporting the participation of children with disabilities in today's classes]. G. Akçamete (Ed.), Genel eğitim okullarında özel gereksinimli olan öğrenciler ve özel eğitim içinde [In Students with special needs and special education in general education schools] (ss.113-139). Ankara: Kök.

Batu, S., \& Kırcaali-İftar, G. (2011). Kaynaştırma [Inclusion]. Ankara: Kök.

Begeny, J. C., \& Martens, B. K. (2006). Assessing pre-service teachers' training in empiricallyvalidated behavioral instruction practices. School Psychology Quarterly, 21(3), 262-285. Doi: 10.1521/scpq.2006.21.3.262.

Block, M. E., \& Obrusnikova, I. (2007). Inclusion in physical education: A review of the literature from 1995- 2005. Adapted Physical Activity Quarterly, 24 (2), 103-124. Doi: 10.1123/apaq.24.2.103. 
Bruwer, M., Hartell, C., \& Steyn, M. (2014). Inclusive education and insufficient school readiness in grade 1: Policy versus practice. South African Journal of Childhood Education. 4(2), 18-35. Retrieved from https://pdfs.semanticscholar.org/6564/b7c5876ba6a932e456088dcec1090dd100ee.pdf.

Bryant, D. P., Smith, D. D., \& Bryant, B. R. (2008). Teaching students with special needs in inclusive classrooms. Boston, MA: Allyn \& Bacon.

Bubpha, S., Erawan, P., \& Saihong, P. (2012). Model development for inclusive education management: Practical guidelines for inclusive schools. Journal of Education and Practice, 3(8), 223233. Retrieved from https://pdfs.semanticscholar.org/b974/37d722f9e519d23779c9aa1482094783890e.pdf.

Büyüköztürk, Ş. (2017). Sosyal bilimler için veri analizi el kitabı: İstatistik, araştırma deseni, SPSS uygulamalarl ve yorum [Data analysis handbook for social sciences: Statistics, research design, SPSS applications and interpretation ] (22.baskı). Ankara: Pegem.

Cagran, B., \& Schmidt, M. (2011). Attitudes of Sşovene teachers towards the inclusion of pupils with different types of special needs in primary school. Educational Studies, 37(2), 171-195. Doi: $10.1080 / 03055698.2010 .506319$.

Carroll, A., Forlin, C., \& Jobling, A. (2003). The impact of teacher training in special education on the attitudes of Australian preservice general educators towards people with disabilities. Teacher Education Quarterly, 30 (3), 65-73. Retrieved from https://files.eric.ed.gov/fulltext/EJ852365.pdf.

Cassady, J. M. (2011). Teachers' attitudes towards the inclusion of students with autism and emotional behavioral disorder. Electuronic Journal of Inclusive Education, 2(7), 1-23. Retrieved from https://corescholar.libraries.wright.edu/ejie/vol2/iss 7/5/.

Ceylan, R., \& Aral, N. (2016). The Opinions of Classroom Teachers and Normally Developing Children on Inclusive Practice. International Online Journal of Educational Sciences (IOJES), 8 (2), 1-11. Doi:10.15345/iojes.2016.02.002.

Combs S., Elliott, S., \& Whipple, K. (2010). Elementary physical education teachers' attitudes towards the inclusion of children with special needs: A qualitative investigation. International Journal of Special Education, 25 (1), 114-125. Retrieved from https://files.eric.ed.gov/fulltext/EJ890572.pdf.

Creswell, J. W. (2014). Araştırma deseni: Nitel, nicel ve karma yöntem yaklaşımları [Research design: Qualitative, quantitative and mixed method approaches] (Çeviri Editörü: Selçuk Beşir Demir). Ankara: Eğiten Kitap

Çankaya, Ö., \& Korkmaz, İ. (2012). İlköğretim I. kademede kaynaştırma eğitimi uygulamalarının sınıf öğretmenlerinin görüşlerine göre değerlendirilmesi. [The Evaluation of Elementary Teachers' Perceptions about Implementation of Inclusive Education]. Kırşehir Eğitim Fakültesi Dergisi $(K E F A D)[$ Kırşehir Faculty of Education Journal (JKEF)], 13(1), 1-16.Retrieved from http://dergipark.ulakbim.gov.tr/aeukefd/article/view/5000086859.

Coşkun, Y. D., Tosun, Ü., \& Macaroğlu. E. (2009). Classroom teachers styles of using and development materials of inclusive education. Procedia - Social and Behavioral Sciences, 1(1), 27582762. Doi:10.1016/j.sbspro.2009.01.489.

David, R., \& Kuyini, A.B. (2012). Social inclusion: Teachers as facilitators in peer acceptance of students with disabilities in regular classrooms in Tamil Nadu, India. International Journal of Special Education, 27(2), 1-12. Retrieved from https://files.eric.ed.gov/fulltext/EJ982870.pdf 
De Boer, A. A., Pijl, S. J., \& Minnaert, A. (2010). Attitudes of parents towards inclusive education: a review of the literature. European Journal of Special Needs Education, 25(2), 165-181. Doi: $10.1080 / 08856251003658694$.

De Boer, A. A., Pijl, S. J., \& Minnaert, A. (2011). Regular primary schoolteachers' attitudes towards inclusive education: a review of the literature. International Journal of Inclusive Education, 15 (3), 331-353. Doi:10.1080/13603110903030089.

Deiner, P. L. (2010). Inclusive early childhood: Development resources and practice (5th ed.). Belmont, CA: Wadsworth Cengage Learning.

Demir, M. K., \& Açar, S. (2011). Kaynaştırma eğitimi konusunda tecrübeli sınıf öğretmenlerinin görüşleri. [Experienced Classroom Teachers' Opinions on Inclusive Education]. Kastamonu Eğitim Dergisi, [Kastamonu Education Journal], 19(3), 719-732. Retrieved from https://dergipark.org.tr/en/download/article-file/817376.

Demirezen, S., \& Akhan, N. E. (2016). Sosyal Bilgiler Öğretmenlerinin Kaynaştırma Uygulamalarına İlişkin Görüşleri. [Social Studies Teachers' Opinions About Inclusion Practices] Abant İzet Baysal Üniversitesi Eğitim Fakültesi Dergisi, 16, (USBES Özel Sayı II), 1206-1223. Retrieved from http://efdergi.ibu.edu.tr/index.php/efdergi/article/view/2086/3084.

Deniz, E., \& Çoban, A. (2019). Kaynaştırma Eğitimine İlişkin Öğretmen Görüşleri. [The Opinions of Tecchers on Inclusive Education]. Elektronik Sosyal Bilimler Dergisi [ Electronic Journal of Social Sciences], 18(70), 734-761. Doi: 10.17755/esosder.448379.

Donohue, D., \& Bornman, J. (2014). The challenges of realising inclusive education in South Africa. South African Journal of Education, 34(2), 1-14. Doi:10.15700/201412071114.

ERG. [REI], (2011). Türkiye'de kaynaştırma/bütünleştirme yoluyla eğitim: politika ve uygulama önerileri. [Turkey Mainstreaming / Integration through Education: Policy and Practice Recommendations]. Retrieved from http://www.egitimreformugirisimi.org/turkiyedekaynastirmabutunlestirme-yoluyla-egitim/.

Forlin, C., Loreman, T., Sharma, U., \& Earle, C. (2009). Demographic differences in changing preservice teachers' attitudes, sentiments and concerns about inclusive education. International Journal of Inclusive Education, 13(2), 195-209. Doi:10.1080/13603110701365356.

Friend, M., Cook, L., Hurley-Chamberlain, D., \& Shamberger, C. (2010). Co-teaching: an illustration of the complexity of collaboration in special education. Journal of Educational \& Psychological Consultation, 20 (1), 9-27. Doi:10.1080/10474410903535380.

Fuchs, W. (2010). Examining teachers' perceived barriers associated with inclusion. Southeastern Regional Association of Teacher Educators Journal, 19(1), 30-35. Retrieved from http://files.eric.ed.gov/fulltext/ej948685.pdf.

Glazzard, J. (2011). Perceptions of the barriers of effective inclusion in one primary school: Voices of teachers and teaching assistants. Support for Learning, 26(2), 56-63. doi:10.1111/j.14679604.2011.01478.x.

Gökdere, M. (2012). Sınıf öğretmenleri ile sınıf öğretmeni adaylarının kaynaştırma eğitimine yönelik tutum, endişe ve etkileşim düzeylerinin karşılaştırmalı incelenmesi. [Comparative analysis of the attitude, anxiety and interaction levels of primary school teachers and primary school teachers towards 
inclusive education]. Educational Science, Theory \& Practice, 12 (4), 2789-2799. Retrieved from http://openaccess.amasya.edu.tr/xmlui/handle/20.500.12450/111\#sthash.Pa75KQ7Z.dpbs.

Gözün, Ö., \& Yıkmış, A. (2004). Öğretmen adaylarının kaynaştırma konusunda bilgilendirilmelerinin kaynaştırmaya yönelik tutumlarının değişimindeki etkililiği.[The effectiveness of informing teacher candidates about inclusion in the change of their attitudes towards inclusion]. Ankara Unniversitesi Eğitim Bilimleri Fakültesi Özel Ĕgitim Dergisi [Ankara University Faculty of Educational Sciences Journal of Special Education], 5(2), 65-77. Doi: 10.1501/Ozlegt_0000000081.

Gürgür, H., Kış, A., \& Akçamete, G. (2012). Kaynaștırma öğrencilerine sunulan bireysel destek hizmetlere ilişkin öğretmen adaylarının görüşlerinin incelenmesi.[Examination of the opinions of preservice teachers about individual support services offered to inclusive students] Illköğretim Online[ Elementary Education Online], 11(3), 689-701. Retrieved from http://ilkogretimonline.org.tr/index.php/io/article/view/1480/1336.

Gürgür, H., \& Hasanoğlu Yazçayır, G. (2019). Türkiye'de Kaynaştırma Eğitimine Yönelik Öğretmenlerin Görüşlerine Odaklanılmış Lisansüstü Eğitim Tezlerinin Sentezlenmesi: MetaEtnografik Bir Çalışma.[Synthesis of Graduate Education Theses Focused on Teachers' Views on Inclusive Education in Turkey: A Meta-Ethnographic Study] Eğitimde Nitel Araşttrmalar Dergisi [Journal of Qualitative Research in Education], 7(2), 845-872. Retrieved from https://dergipark.org.tr/tr/pub/enad/issue/45025/561448.

Güven, D. (2019). Zihin yetersizliği olan öğrencilerin devam ettiği destek eğitim odası hizmetine yönelik bir durum çalışması. [A case study for resource room service attended by students with intellectual disability].Yayımlanmamış Yüksek Lisans Tezi.[Unpublished Master's Thesis]. Anadolu Üniversitesi Eğitim Bilimleri Enstitüsü, Eskişehir. Retrieved from https://tez.yok.gov.tr/UlusalTezMerkezi/.

Güven, Y., \& Balat, G. U. (2006). Kaynaştırma uygulamalarına ilişsin rehber öğretmenler ve rehberlik araştırma merkezi çalışanlarının görüşleri.[ School Counselors' and Counceling and Research Centers Specialists' Views about Integration]. Atatürk Ĕ̈itim Fakültesi Ĕgitim Bilimleri Dergisi, [Atatürk Faculty of Education Journal of Educational Sciences] 24, 95-108. Retrieved from http://dspace.marmara.edu.tr/bitstream/handle/11424/1521/1382-2445-1-

SM.pdf? sequence $=1 \&$ isAllowed $=\mathrm{y}$.

Haug, P. (2017). Understanding inclusive education: ideals and reality. Scandinavian Journal of Disability Research, 19(3), 206-217. Doi:10.1080/15017419.2016.1224778.

Hallahan, D. P., \& Kauffman, J. M. (2003). Exceptional learners: Introduction to special education (9th ed.). Boston: Allyn and Bacon.

Hemmingsson, H., Gustavsson, A., \& Townsend, E. (2007). Students with disabilities participating in mainstream schools: Policies that promote and limit teacher and therapist cooperation. Disability and Society, 22(4), 383-398. Doi: 10.1080/09687590701337892.

Hui, M. S. (2015). Factors influencing the success of inclusive practices in Singaporean schools: Shadow teachers perspectives. Unpublished Master Thesis. Universiteteti Oslo, Reprosentralen. Retrieved from https://www.duo.uio.no/handle/10852/49454.

Kayhan, N., Şengül, A., \& Akmeşe, P. (2012). First and second stage of primary teachers candidates investigation on the opinions of mainstreamining. Journal of Research in Education and Teaching, 1(3), 268-278. Retrieved from http://www.jret.org/FileUpload/ks281142/File/28z.kayhan.pdf. 
Kuyini A. B., \& Desai, I. (2008). Providing instruction to students with special needs in inclusive classrooms in Ghana: Issues and challenges. International Journal of Wholeschooling, 4(1) 22-38. Retrieved from https://files.eric.ed.gov/fulltext/EJ834291.pdf.

Lee, L. W., \& Low, H. M. (2013). Unconscious' inclusion of students with learning disabilities in a Malaysian mainstream primary school: Teachers' perspectives. Journal of Research in Special Educational Needs, 13(3), 218-228. Doi:10.1111/j.1471-3802.2012.01250.x.

Mastropieri, M., \& Scruggs, T. (2010). The inclusive classroom: Strategies for effective differentiated instruction. Upper Saddle River, NJ: Pearson.

Mateusi, C. M., Khoaeane, J. T., \& Naong, M. N. (2014) Challenges of Inclusive Education: Lesotho Case Study. International Journal of Educational Sciences, 6(2), 263-273. Doi: 10.1080/09751122.2014.11890138.

McCray, E. D., \& McHatton, P. A. (2011). "Less afraid to have them in my classroom": Understanding pre-service general educators' perceptions about inclusion. Teacher Education Quarterly, 38(4), 135-155. Retrieved from https://files.eric.ed.gov/fulltext/EJ960622.pdf.

McMillan, M. (2008). Inclusive education: The benefits and the obstacles. Brockport, NY: State University of New York College at Brockport. Retrieved from http://digitalcommons.brockport.edu/ehd_theses/445.

MEB [MoNE]. (2013). Bütünleştirme kapsamında eğitim uygulamaları. [Educational practices within the of scope integration] from https://orgm.meb.gov.tr/kitaplar/Butunlestirme_Kapsaminda_Egitim_Uygulamalari_Ogretmen_Kilavu z_Kitabi.pdf.

MEB. [MoNE]. (2017). Kaynaştırma/bütünleştirme yoluyla eğitim uygulamaları genelgesi. [Circular of educational practices through inclusion / integration]. (2017/28). Retrieved from https://orgm.meb.gov.tr/meb_iys_dosyalar/2017_09/21112929_kaynastirma_genelge.pdf.

MEB. [MoNE]. (2018). Özel ĕgitim hizmetleri yönetmeliği.[Special Education Services Regulation] Ankara: MEB Yayınları.

MEB. [MoNE]. (2019). Milli Eğitim Bakanlı̆̆ strateji geliştirme başkanlı̆̆ istatistikleri örgün eğitim. [Ministry of National Education Strategy Development Presidency Statistics Formal Education ]. Retrieved from https://sgb.meb.gov.tr.

Metin, N. (2018). Okul öncesi kaynaştırma sınıfinda öğretmen [Teacher in pre-school inlusion class]. Erken Çocukluk Çalışmaları Dergisi [Journal of Early Childhood Studies], 2(2), 428-439. Doi:10.24130/eccdjecs.196720182279.

Miles, M. B., \& Huberman, A. M. (2015). Genişletilmiş bir kaynak kitap: Nitel veri analizi. [An extended resource book: Qualitative data analysis]. (S. Akbaba Altun ve A. Ersoy, Çeviri Editörleri). Ankara: Pegem.

Noyes, A. (2004). Producing Mathematics Teachers: A sociological perspective. Teaching Education, 15(3), 243-256. Doi:10.1080/1047621042000257180.

O’Gorman, E., \& Drudy, S. (2011). Professional Development for Teachers Working in Special Education/Inclusion in Mainstream Schools. Research Report. Dublin: UCD. 
Obiakor, F. E., Harris, M., Mutua, K., Rotatori, A., \& Algozzine, B. (2012). Making inclusion work in general education classrooms. Education \& Treatment of Children, 35(3), 477-490. Retrieved from https://www.jstor.org/stable/42900597?seq=1.

Patton, M. Q. (2014). Nitel araştırma ve değerlendirme yöntemleri [Qualitative research and evaluation methods]. (M. Bütün \& S. B. Demir, Çev. Ed.) Ankara: Pegem Akademi.

Rodriguez, C. C., \& Garro-Gil, N. (2015). Inclusion and Integration on Special Education. Procedia Social and Behavioral Sciences, 191, 1323-1327. Doi:10.1016/j.sbspro.2015.04.488.

Sadioğlu, Ö., Batu, E. S., \& Bilgin, A. (2012). Sınıf öğretmenlerinin özel gereksinimli öğrencilerin kaynaştırılmasına ilişkin görüşleri. [Primary School Teachers' Opinions Related to Inclusion of Students With Special Needs]. Uludă̆ Eğitim Fakültesi Dergisi [Journal of Uludağ Education Faculty], 25(2), 399-432. Retrieved from https://dergipark.org.tr/tr/pub/uefad/issue/16696/173558.

Sadioğlu, Ö., Bilgin, A., Batu, S. \& Oksal, A. (2013). Sınıf öğretmenlerinin kaynaştırmaya ilişkin sorunlar1, beklentileri ve önerileri. [Problems, Expectations, and Suggestions of Elementary Teachers Regarding Inclusion]. Kuram ve Uygulamada Eğitim Bilimleri [Educational Sciences: Theory \& Practice], 13(3), 1743-1765. Doi:10.12738/estp.2013.3.1546.

Salend, S.J. (2011). Creating inclusive classrooms: Effective and reflective practices. Boston: Pearson.

Saraç, T., \& Çolak, A. (2012). Kaynaştırma uygulamaları sürecinde ilköğretim sınıf öğretmenlerinin karşılaştıkları sorunlara ilişkin görüş ve önerileri. [Opinions and suggestions regarding the problems faced by primary school teachers in the process of inclusive practices]. Mersin Üniversitesi Eğitim Fakültesi Dergisi [Mersin University Faculty of Education Journal], 8(1), 13-28. Retrieved from https://dergipark.org.tr/en/download/article-file/160833.

Scruggs, T. E., \& Mastropieri, M. A. (1996). Teacher perceptions of mainstreaming/inclusion, 19581995: A research synthesis. Exceptional Children, 63(1), 59-74. Doi:10.1177/001440299606300106.

Seçer, Z., Sarı, H., \& Çetin, Ş. (2010). Okul öncesi dönemdeki çocukların bedensel engelli akranları ile birlikte eğitim almalarına ilişkin görüşleri. [Opinions of preschool children about their education with their physically disabled peers]. Gazi Üniversitesi Endüstriyel Sanatlar Ĕ̈itim Fakültesi Dergisi [Gazi University Journal of Industrial Arts Education Faculty], 26, 12-24. Retrieved from https://dergipark.org.tr/tr/download/article-file/296425.

Shady, S. A., Luther, V. L., \& Richman, L. J. (2013). Teaching the teachers: A study of perceived professional development needs of educators to enhance positive attitudes toward inclusive practices. Education Research and Perspectives, 40(1) 169-191. Retrieved from https://eric.ed.gov/?id=EJ1007199.

Sharma, U., Forlin, C., \& Loreman, T. (2008). Impact of training on pre-service teachers' attitudes and concerns about inclusive education and sentiments about persons with disability. Disability and Society, 23(7), 773-785. Doi: 10.1080/09687590802469271.

Sharma, U., Loreman, T., \& Forlin, C. (2011). Measuring teacher efficacy to implement inclusive practices: An international validation. Journal of Research in Special Educational Needs, 12(1), 1221. Doi:10.1111/j.1471-3802.2011.01200.x.

Slobodzian, J. T. (2009). The devil is in the details: Issues of exclusion in an inclusive educational environment. Ethnography and Education, 4(2), 181-195. Doi:10.1080/17457820902972804.

Anatolian Journal of Education, April $2021 \bullet$ Vol.6, No.1 
Smith, D. D, Tyler, N., Skow, K., Stark, A., \& Baca, L. (2003). Effective inclusion of students with disabilities in general education classrooms. The IDEA and Research for Inclusive Settings Center. Retrieved from https://files.eric.ed.gov/fulltext/ED473260.pdf4.

Sucuoğlu, B., \& Akalın, S. (2010). Kaynaştırma sınıflarına alternatif bir bakış: Çevresel davranışsal değerlendirme ile öğretimsel özelliklerin incelenmesi. [Eco-behavioral Assessment: An Alternative Method for Assessing Mainstreamed Classrooms in Turkey]. Ankara Üniversitesi Eğitim Bilimleri Fakültesi Özel Eğitim Dergisi [Ankara University Faculty of Educational Sciences Journal of Special Education], 11(1), 19-37. Doi: 10.1501/Ozlegt_0000000144.

Şahbaz, Ü., \& Kalay, G. (2010). Okulöncesi eğitimi öğretmen adaylarının kaynaştırmaya ilişkin görüsslerinin belirlenmesi. [The Determination of Views of Pre-School Student Teachers Related With Inclusion]. Mehmet Akif Ersoy Üniversitesi Eğitim Fakültesi Dergisi [Mehmet Akif Ersoy University Journal of Education Faculty], 10(19), 116-135. Retrieved from https://dergipark.org.tr/en/download/article-file/181297.

Taylor, R. L., Smiley, L. R., \& Richards, S. B. (2009). Exceptional students: Preparing teachers for the 21 st century. New York, NY: McGraw-Hill.

TÜİK. [TurkStat] (2002). Engelli istatistikleri. [Disabled statistics]. Retrieved from http://www.tuik.gov.tr/PreTablo.do?alt_id=1017.

Türkiye Özürlüler Araştırması [Turkey Disability Survey]. (2002). Aile ve Sosyal Politikalar Bakanlığı Engelli ve Yaşlı Hizmetleri Genel Müdürlüğü. [Ministry of Family and Social Policies, Disabled and Elderly Services General Directorate]. Retrieved from http://www.eyh.gov.tr/upload/ozurluveyasli.gov.tr/mce/eski_site/arastirma/tr_ozurluler_arastirmasi/bl m1.pdf

Ünay, E. (2015). Destek oda eğitiminin kaynaştırma öğrencilerinin matematik başarıları üzerine etkisi. [The effect of the resource room education on the mathematics achievement of the mainstreaming students]. Buca Eğitim Fakültesi Dergisi [Journal of Buca Education Faculty], 40, 38-49. Retrieved from https://dergipark.org.tr/en/download/article-file/231516.

Worrell, J. (2008). How secondary schools can avoid the seven deadly school "Sins" of inclusion. American Secondary Education, 36 (2), 43-56.

Yatgın, S., Sevgi, H. M., \& Uysal, S. (2015). Sınıf öğretmenlerinin kaynaştırma eğitimine ilişkin görüşleri ve çeşitli değişkenlere göre mesleki tükenmişliklerinin incelenmesi [Classroom teachers' opinions on inculusive education and investıgation of their occupational burnout according to various variables]. Abant İzzet Baysal Üniversitesi Eğitim Fakültesi Dergisi [Abant Izzet Baysal University Journal of Faculty of Education], 15 (Special Number), 167-180. Doi:10.17240/aibuefd.2015.15.05000128650 .

Yaylac1, Z., \& Aksoy, B. (2016). Sosyal Bilgiler Öğretmenlerinin Kaynaştırma Eğitimindeki Yeterlilikleri. [Competence of Social Science Teachers in Inclusive Education]. Uluslararası Türk Eğitim Bilimleri Dergisi [The International Journal of Turkish Education Sciences], 2016(6), 19-40. Retrieved from https://dergipark.org.tr/tr/pub/goputeb/issue/34311/379157.

Yıldırım, A., \& Şimşek, H. (2013). Sosyal bilimlerde nitel araştırma yöntemleri. [Qualitative research methods in the social sciences]. Ankara: Seçkin. 
Yılmaz, E., ve Melekoğlu, M. A. (2018). Kaynaştırma Eğitiminin Yasa ve Uygulamalardaki Durumunun Türkiye ve Avrupa Bağlamında Değerlendirilmesi. [The status of Inclusive Education in Law and Practice Assessment in Turkey and the European Context]. Osmangazi Journal of Educational Research (OJER), 5(1), 1-17.

Yin, R. K. (2011). Qualitative research from start to finish. New York, London: The Guilford Press.

YÖK. [CoHE]. (2018). Yeni Öğretmen Yetistirme Lisans Programları. [New Teacher Training

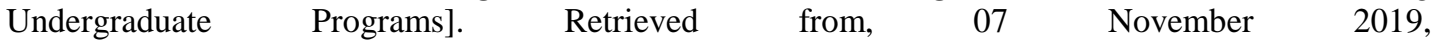
https://www.yok.gov.tr/kurumsal/idari-birimler/egitim-ogretim-dairesi/yeni-ogretmen-yetistirmelisansprogramlari. 